\title{
ON THE SYNTAX OF VERB-INITIAL EXCLAMATIVES
}

\author{
Ellen Brandner
}

\begin{abstract}
This article discusses exclamative utterances that have the form of $\mathrm{Y} / \mathrm{N}$ questions with no wh phrase present but only the finite verb in initial position. It will be shown that they cannot be captured by a purely pragmatic 'reinterpre tation' of $\mathrm{Y} / \mathrm{N}$ questions. This result implies that verb initial structures are syntactically ambiguous. An alternative to the traditional view on clause types as features/operators in the $\mathrm{C}$ domain, triggering $\mathrm{V} \mathrm{C}$ movement, will be suggested. V C movement marks syntactically all those structures that correspond to non assertive speech acts. The structures are disambiguated by non syntactic means like intonation and/or lexical triggers.
\end{abstract}

\section{Introduction}

It is a well known fact that exclamatives show a rather variable syntax in contrast to more restricted sentence types like interrogatives and declaratives. For this reason, they are an interesting testing ground for theories concerned with sentence types and their syntactic marking. Approaches range from the assumption that there is no exclamative syntax at all and that the exclamative interpretation can be imposed basically on any sentence type, see e.g. Sæbø (2006) to more syntactically oriented analyses that posit an exclamative feature or operator in the (expanded) C-layer, see e.g. Bennis et al. (1998), also Gutièrrez-Rezach (1996). The common property of the syntactic approaches is the assumption that the clause type 'exclamative' is directly represented in the syntax in the form of a syntactic feature/operator that has to be checked and is therefore responsible for the syntactic surface form. A position somehow in between is held by Zanuttini and Portner (2003) who see the exclamative interpretation as the result of various semantic and syntactic properties coming together in one utterance. One of these is that exclamatives are factive in contrast to interrogatives, see Elliott

This article grew out of collaboration with Hans Georg Obenauer. Many thanks to him for all the discussion and the examples/problems he drew my attention to. Many thanks also to Ingrid Kaufmann for the discussion on clause types in section 4 and 5 . Thanks also to Josef Bayer, Marcel den Dikken, Uli Lutz, Susanne Trissler and to the audience of the NORMS workshop on exclamatives, October 2007, Tromsø, two anonymous reviewers, Klaus Abels and especially to Øystein Vangsnes. All remaining errors and shortcomings are my own. This work is funded by the DFG via SFB 471 A17 and by the CNRS, Paris (Fédération TUL FR 2559). 
(1974), Grimshaw (1979), also Abels (this volume) and Saebø (this volume). ${ }^{1}$ On the other hand, exclamatives show basically the syntax of interrogatives. The incompatibility of factivity with a question leads to the exclamative interpretation via pragmatic inference. These factors may have a syntactic reflex, distinguishing exclamatives from interrogatives. Crucially, there is no unique exclamative syntax in the strict sense.

In this paper I will contribute to this discussion by a detailed examination of a rather rarely discussed type of exclamatives, so called $\mathrm{Y} / \mathrm{N}$ exclamatives, due to their structure which is identical to $\mathrm{Y} / \mathrm{N}$ questions, exemplified for English in (1): ${ }^{2}$

(1) Boy, is syntax easy!

In German, these are quite wide-spread and are used as an alternative to the familiar (and much more discussed) wh-exclamatives. In the following I will use the more neutral term "verb-initial exclamative" (V1E) for the construction in (2a).

(2) a. Ist Syntax einfach!

V1E Is syntax easy

b. Wie einfach Syntax ist! how easy syntax is

Wh-exclamative

V1E obviously exhibit V-C movement - although the lack of it in wh-exclamatives is claimed to be the distinctive syntactic property between interrogatives and exclamatives:

(3) a. How cute the baby is !/*?

b. How cute is the baby $* ! /$ ?

The lack of $\mathrm{V}-\mathrm{C}$ movement in (3a) is taken to be clear evidence that there is a separate clause type 'exclamative' with a syntactic form that is exclusively tied to this specific interpretation, see Elliott (1974). ${ }^{3}$ However, if the lack of $\mathrm{V}-\mathrm{C}$ movement is the distinctive property between the two interpretations, then V1 clauses, which necessarily involve $\mathrm{V}-\mathrm{C}$ movement, should never acquire the sentence type 'exclamative'. So the problem that arises by the mere existence of V1E is (i) how

\footnotetext{
${ }^{1}$ Factivity is the reason why interrogative verbs cannot embed exclamatives, despite their 'wh syntax', see Abels (2007, this volume) for detailed discussion. The fact that exclamatives can be embedded is of course crucial for the question whether they constitute a clause type of their own, since the possibility of embedding them immediately excludes a purely 'pragmatic' account in terms of re interpretation. But since verb initial structures can never be embedded for independent reasons, embeddability will not play a role for the discussion in this paper.

${ }^{2}$ The example in (1) is actually the title of a paper.

${ }^{3}$ See especially Obenauer $(1994,2004)$ for a very careful investigation of syntactic dif ferences that induce the exclamative reading and other non standard interrogative inter pretations.
} 
the exclamative interpretation is possible, (ii) how verb-movement is triggered in these cases, and (iii) how they interact with $\mathrm{Y} / \mathrm{N}$ questions.

I will proceed as follows: Section 2 gives a brief overview about V1Es in the Germanic languages in order to show that V1E are by no means 'marginal' but should be accounted for in a general theory about clausal typing. After that I will discuss the idea that V1E are $\mathrm{Y} / \mathrm{N}$ questions from a syntactic point of view but pragmatically re-interpreted. A view that is advocated in Huddleston (1993) and in some sense also in Zanuttini and Portner (2003). It will be shown that pragmatic re-interpretation is not sufficient to account for the whole range of data. The next issue is to establish that V1E indeed have the same distribution and the same properties as the corresponding wh-exclamatives. This is the topic of section 3 where I will argue that the distinctive properties of exclamatives are (i) a degree component, following Castroviejo (2006) and Rett (to appear), and (ii) that exclamatives always involve the expression of the 'evaluation on side of the speaker'. The result of this discussion will be that V1E indeed have the relevant properties and thus must be classified as belonging to the clause type 'exclamative'. This result raises the question in which sense a specific syntax is connected to a clause type, given that the same clause type, namely exclamative, can be realized either with or without V-C movement. Furthermore, since V1E have the same syntax as $\mathrm{Y} / \mathrm{N}$ questions, the problem holds also the other way round: How is it possible that one and the same syntactic structure can have two different interpretations?

In section 4 I will sketch an account of clausal typing which entails more flexibility with respect to the trigger for $\mathrm{V}-\mathrm{C}$ movement. The crucial idea is that $\mathrm{V}-\mathrm{C}$ movement is merely the syntactic basis of an utterance that is not interpreted as a plain assertion. The specific value (e.g. exclamative or interrogative) cannot be read off directly from the syntactic structure. Instead, non-syntactic means like intonation and/or certain lexical triggers deliver the actual value. A syntactic string like

(4) Ist die schön

is she nice

'Is she nice?/How nice she is!'

is ambiguous from a purely syntactic point of view. In order to capture this ambiguity, I will suggest that there is no clause type feature directly represented in the syntax that triggers verb movement in the sense of a checking mechanism. Instead, the syntax 'hands over' a premature structure encoding only the 'instruction' that a structure with $\mathrm{V}-\mathrm{C}$ movement is not to be interpreted as a plain assertion. The paper should be understood as programmatic in nature. Here, I can merely show that the syntactic mechanisms to assign clause types are limited in the sense that not every clause type is uniquely identified by purely syntactic mechanisms. 


\section{Ellen Brandner}

\section{A brief overview of V1E in Germanic}

Some further examples of V1E in German are given in (5a-7a), involving verbs, adverbs, and adjectives. They can be used as an alternative to whexclamatives, illustrated in the b.-sentences; these show the same characteristics as their English counterparts: A wh-degree word (wie) is fronted and the finite verb stays in its base position:

(5) a. Hat der sich aufgeregt!

has he REFL fussed

'How he fussed!'

b. Wie der sich aufgeregt hat!

how he REFL fussed has

'How he fussed!'

(6) a. Hat die schön gesungen!

has she nicely sung

'How nice she has sung!'

b. Wie die schön gesungen hat!

How she nicely sung has

'How nice she has sung!'

(7) a. Haben die ein tolles Haus!

have they a fancy house

'What a fancy house they have!'

b. Was die für ein tolles Haus haben!

what they for a fancy house have

'What a fancy house they have!'

In German, V1E can occur without a particle or other material preceding them - in contrast to English V1E. ${ }^{4}$ Dutch on the other hand seems to allow V1E just as easily as German, cf. (9):

(8) Boy, is syntax easy!

(9) a. Heeft Jan even een boeken gekocht! ${ }^{5}$

(Corver 1990:114) has Jan just a books bought 'How many books jan has bought!'

b. Heeft hij me toch (een) mooie boeken gekocht! (Bennis 1998:34) has he me MP (a) nice books bought

'What nice books he has bought!'

\footnotetext{
${ }^{4}$ I have nothing to say about this contrast, but since it does not affect the issues to be raised about verb movement, I will ignore this difference in the following. However, it should be noted that in written German, these introducing 'particles' seem to occur more often.

${ }^{5}$ Note that een in this example is an instance of a 'spurious' een, i.e. it does not express number and is thus compatible with plural nouns, see Bennis et al. (1998).
} 
In other Germanic languages, V1Es seem to be less common than in German and Dutch but they are by no means impossible. In Swedish, for example, V1E are acceptable - at least in spoken language. But they are not as productive as in German, since they cannot occur with nominal degree expressions, as reported in Delsing (2007), see (10c).

(10) a. ÄR jag trött!

am I tired

'How tired I am'

b. HAR jag jobbat idag!

have I worked today

'I have worked like hell today'

c. ${ }^{? ?}$ ÄR han en idiot!

is he an idiot

As indicated in the examples via the capitals, stress must be on the finite verb in these Swedish examples. This is different in German where stress can occur on other constituents as well:

(11) a. IST das laut hier!

is that noisy here

b. Ist das LAUT hier!

is that noisy here

'How noisy it is, here!'

Danish allows V1E more readily, but again they are not as common as in German (Anne Kjeldahl p.c.). The following example is perfectly acceptable:

(12) Har jeg *(bare) arbejdet meget i dag! have I PRT ( $\approx$ just) worked a lot today 'How much I have worked today!'

As indicated, the particle bare must occur - otherwise there is no exclamative interpretation. I will come back to the role of particles in the next section.

In Icelandic, on the other hand, V1E are restricted to a certain class of verbs, see Jónsson (2007). ${ }^{6}$

(13) Kemur Jón

comes John

'Look, John is coming'

\footnotetext{
${ }^{6}$ Halldór Sigurðsson (p.c.) provided me with some further examples; however they all involve typical achievement verbs (come, explode, ring (the phone), etc.). As will be discussed below, these are verbs that are completely out as V1E in German. In contrast, the gradable verbs typical for the German construction are only possible as wh exclamatives in Icelandic. I have nothing to say about this here.
} 
(14) Hringir sím inn!

rings the telephone

'Hey, the telephone is ringing'

They have a different pragmatic function than in the other Germanic languages and are used "to bring the listener's attention to what is happening" (Jónsson 2007: 1). Because of this different nature, I will neglect them in the following.

This brief survey about V1E in Germanic shows that V1Es are licit syntactic structures in nearly all Germanic languages and thus by no means 'marginal'. Whatever the reasons for the more restrictive usage in some languages are, they are not a consequence of a principled syntactic prohibition against an exclamative interpretation of a V1 structure. In the following discussion, I will draw the data from German and I will leave it to future research to which extent the generalizations and analyses for German can be transferred to the other Germanic languages.

\section{V1E as $\mathrm{Y} / \mathrm{N}$ questions in 'disguise'?}

This section discusses that a re-interpretation approach is not sufficient to account for the properties of V1E. It will be shown that intonation has only a limited impact on clause typing. The same holds for certain modal particles and other lexical triggers which can be used to disambiguate the structure. After that I will show in detail that V1E pattern with wh-exclamatives in all relevant respects.

\subsection{Intonation as a clause typer?}

One possibility to deal with the problems that arise by the mere existence of $\mathrm{V} 1 \mathrm{E}$ is to analyze them as pragmatically re-interpreted $\mathrm{Y} / \mathrm{N}$ questions; a view that is explicitly defended in Huddleston (1993) to whose analysis I will come back below. Under such a perspective, V1E are mere 'exclamations'. By invoking a non-canonical intonation contour, the $\mathrm{Y} / \mathrm{N}$ question, which has been derived by verb movement to $\mathrm{C}$ in order to check the wh-feature, is turned into an exclamative, i.e. the $\mathrm{Y} / \mathrm{N}$ interpretation is cancelled:

$$
\begin{gathered}
{[\mathrm{CP} Y / \mathrm{N} \text { Ist das einfach]! }} \\
\text { is that easy }
\end{gathered}
$$

As will become clear immediately, such an approach raises more problems than it solves. One is how to treat the syntactic clause type feature after the re-interpretation process. Does it somehow 'loose' its value? If yes, what is the exact mechanism? Does this mean that intonation has the same syntactic status as a clause type feature? I will 
present arguments showing (i) that the 'original' syntax is still accessible in a clause that is re-interpreted via intonation, cf. rising declaratives below, and (ii) that e.g. wh-interrogatives resist any re-interpretational process, i.e. the various clause types are 'susceptible' to reinterpretation to different degrees. Thus, the re-interpretation process is sensitive to the exact feature specification of the clause. These asymmetries should be accounted for in a principled way, since there is no obvious reason why the wh-feature in $\mathrm{Y} / \mathrm{N}$ questions can be cancelled but not in whquestions. On the other hand, we will see that verb-initial structures do not show any restrictions of the kind just mentioned. The reason is - as I will suggest - that verb-initial structures are not syntactically specified and that therefore no 're-interpretation' is at stake, rather the intonation contour is used as a last resort to give the clause an interpretation at all.

Let us first turn to the well-known example for the 'overwriting' mechanism, namely 'rising declaratives', as discussed in detail in Gunlogson (2001):

(16) Er kommt auch $\uparrow$ ?okay

he comes too

With the appropriate rising intonation, (indicated by the arrow), this declarative clause can be used as a $\mathrm{Y} / \mathrm{N}$ question. However, as Gunlogson shows, rising declaratives are biased since the environments where they are licit are not identical to those of $\mathrm{Y} / \mathrm{N}$ questions. For example, rising declaratives cannot be used as exam questions or in a court situation. More interestingly, they cannot be the follow-up in a situation where the question character is explicitly introduced, as illustrated in (17) and (18):

(17) It's an open question.

a. Did she lie to the grand jury?

b. \#She lied to the grand jury?

c. \#She lied to the grand jury.

(18) a. The question is, does he have the money?

b. The question is, \# he has the money?

c. The question is, \# he has the money.

Furthermore, they do not license negative polarity items:

(19) *Anybody is at home?

Gunlogson's main insights can be summarized as follows: The assertive nature of the declarative clause type is not 'cancelled' or 'overwritten'. The rising intonation rather shifts the commitment to the proposition from the speaker to the addressee. To put it differently: A rising declarative is only adequate in a situation where the speaker takes the 
addressee to be "knowledgeable" on the subject. (19) shows that the clause is still assertive because negative polarity items are only possible in what is called 'non-veridical contexts', i.e. contexts where the truth value is not known, see Giannakidou (1998).

A further problem for an 'intonational' approach is that its application is limited. Consider the following wh-interrogative:

(20) Was hast du den Kindern mitgebracht? what have you the children-DAT with-brought 'What did you bring along for the children?'

This structure can only be interpreted as a question and never as a declarative or as an exclamative. ${ }^{8}$ An obvious explanation would be that this is due to the presence of the wh-word. But note that at least in German, the "wh-word" was can also be used as an indefinite:

(21) Er hat den Kindern was mitgebracht.
$\mathrm{He}$ has the children-DAT something with-brought
'He has brought something for the children'

The wh-word per se thus does not lead to an interrogative interpretation, rather it is the syntactic configuration that is relevant, i.e. $\mathrm{V}-\mathrm{C}$ movement together with the wh-word in Spec-CP. This is of course well known, the crucial point here is that (20) can never be re-interpreted - even with the "best" declarative intonation and the "best" plausible context. In contrast, the declarative in (21) is open to the declarative as well as to the rising declarative interpretation. So intonation is not able to cancel the question interpretation in the case of a wh-interrogative. To cast it in syntactic terms: The wh-feature in a $\mathrm{Y} / \mathrm{N}$ question, as in (15) can be overwritten but the wh-feature in a wh-question as in (20) cannot. Given that the syntactic structure of both types of questions is assumed to be alike (with the sole difference that Spec-CP hosts an empty operator in case of a $\mathrm{Y} / \mathrm{N}$ question), this asymmetry is unexpected.

The third problem for the assumption that intonation 'plays in the same league' as the syntactic devices is its limited applicability in embedded clauses. If a matrix verb selects for an interrogative and the embedded clause is introduced by a declarative complementizer there is no way to re-interpret this clause as a question, even if an appropriate intonation is chosen. The idea, that intonation belongs to the inventory

\footnotetext{
${ }^{7}$ Gunlogson uses the term 'public committed', I will use the more neutral term 'knowl edgeable' which has a somewhat broader application in that also covers the supposition on side of the speaker about the knowledge state of the addressee. Thanks to Elena Castroviejo (p.c) for bringing up this term. I hope I do justice to what she had in mind. The notion will become important in section 4 .

${ }^{8}$ It can be interpreted as rhetorical question if a specific intonation is used. However, the important distinction between rhetorical questions and exclamatives is that the former can indeed be answered, i.e. the 'original speech act' is still accessible, see Obenauer (1994) for detailed discussion.
} 
of markers for the syntactic clause type - a view that is suggested e.g. by Cheng and Rooryck (2000) - cannot be upheld.

The result of this discussion can be summarized as follows:

(22) a. Declaratives are susceptible for re-interpretation

b. Wh-interrogatives resist re-interpretation

On the other hand, verb-initial structures like in (15) escape these restrictions. This asymmetry should find a principled explanation and I think the above considerations have shown that this cannot be relegated to pragmatic re-interpretation processes, based on intonation contours.

\subsection{Lexical triggers}

A purely pragmatic approach, as defended in Huddleston (1993), will not be able to cope with the following data:
a. Hat der
Geld ???
b. Hat der ein Geld*?/!
has he (a) money

(24)
a. Machen die
Lärm ?/?!
b. Machen die
einen Lärm*?/! make they
(a) noise
a. Spricht der
Deutsch ?/*!
b. Spricht der ein Deutsch*?/! speaks he (a) German

The nouns in (23)-(25) are mass nouns and do normally not occur with indefinite determiners. However, an indefinite determiner is licit if the clause is used as an exclamative. Moreover, its presence prohibits a $\mathrm{Y} / \mathrm{N}$ interpretation whereas the lack of it prohibits the exclamative interpretation - irrespective of the intonation contour. ${ }^{9}$ McCawley (1973) lists various similar examples (e.g. NPIs like any are not licit in V1E, coordinated questions of the form $\mathrm{p}$ or $\square \mathrm{p}$ cannot be used as V1E, etc.) in order to show that $\mathrm{Y} / \mathrm{N}$ questions and V1E are "something completely different". Many of the properties that McCawley (1973) lists are not valid also in my view, e.g. that emotive, evaluative adverbs/adjectives cannot be used in V1E. Is it delicious? is a perfect question. I also agree with Huddleston (1993) in his critique that these properties do not show that $\mathrm{V} 1 \mathrm{E}$ have a different syntax than $\mathrm{Y} / \mathrm{N}$ questions, as will become

\footnotetext{
${ }^{9}$ As can be seen by the judgements, the lack of the determiner does not always lead to a non exclamative interpretation. Nouns that are inherently gradable and that have an evaluative component in them, like noise can be an exclamative without the determiner. Note that a neutral noun like sound patterns with the other examples. I will come back to these components in section 3.3.
} 
clear in section 4. However, a purely pragmatic based explanation in terms of indirect speech acts is not viable either. Huddleston tries to explain the lexical restrictions of the kind illustrated in (23-25) by claiming that simply only a subset of $\mathrm{Y} / \mathrm{N}$ questions can be the base of a re-interpretation process. This holds for more familiar indirect speech acts as well. A question like Was it Bill who had opened the door? can hardly be used as a directive (in contrast to the question Would you mind opening the door? or a declarative like The door is still closed). But Huddleston overlooks the important fact that - despite their V1 structure - the b.-examples cannot be used as $\mathrm{Y} / \mathrm{N}$ questions either. If a question or declarative resists re-interpretation as a command in a typical indirect speech act like those just mentioned, they can be interpreted as a question or as a declarative nevertheless and they build a well-formed utterance by themselves. The indirect speech act simply does not work the way the speaker intends. (The addressee could respond with Yes, $I$ mind or I know instead of opening the door). Things are different with the examples in (23-25). Although the a.-examples could be explained via a non-felicitous speech act, cf. also the difference in acceptability, the b.-examples can never surface as a $\mathrm{Y} / \mathrm{N}$ question - as a matter of grammaticality. For this reason, pure pragmatics in the sense of re-interpretation is not sufficient to account for V1E, contrary to what is claimed in Huddleston (1993).

Similar considerations apply to the following examples, containing modal particles, see Näf (1987) and Hasegawa (1999) for detailed discussion.

(26) a. Hat der sich aber aufgeregt!/*?

has he PRT (=but) fussed

b. Hat der sich eigentlich aufgeregt $* ! /$ ?

has he PRT (= actually) fussed

The particle aber 'but' in (26a) leads unambiguously to an exclamative interpretation whereas eigentlich 'actually' allows the interrogative interpretation only. Again, there is no $\mathrm{Y} / \mathrm{N}$ interrogative basis from which the exclamative could be derived (and vice versa). Both particles operate on the truth conditions of the clause. Eigentlich emphasizes the fact that the speaker is not knowledgeable, i.e. s/he demands an answer to the question. Aber as a modal particle is typically used when the speaker objects to a previously stated assertion. In exclamatives, the interpretation is slightly different. In this context, aber emphasizes that the proposition either exceeds or is in conflict with the expectations of the speaker. This interpretation is akin to its original meaning with the difference that the speaker objects to his 'own assertion' (defined by his expectations), so to speak. 
However, like intonation above, these particles are not solely responsible for the exclamative interpretation. ${ }^{10}$ First, note that these particles cannot be used in an embedded clause, irrespective of a construal as whexclamative (27b) or as 'simulated bare-exclamative' with the neutral determiner dass (that), cf. (27a):
a. Ich bin erstaunt dass der sich (*aber) aufgeregt hat I am amazed that he REFL PRT (=but) fussed has
b. Ich bin erstaunt wie der sich (*aber) aufgeregt hat I am amazed how he REFL PRT (=but) fussed has

An independent declarative clause acquires an exclamative interpretation, if the particle aber is added, cf. (28), but it is equally possible to interpret (28) as a declarative with the additional expression of 'disagreement' to another statement (indicated by the period):

(28) Der hat sich aber

he has REFL PRT (= but) fussed

Evidence for the availability of the declarative reading is the fact that (28) can be denied in a follow-up like No, this is simply not true. What we find here is very similar to the rising declaratives discussed in section 3.1: The traits of the assertion expressed via the declarative sentence type are still present and can be taken up in a response - although pragmatically the exclamative interpretation is clearly foregrounded.

The declarative interpretation is also available for the examples in (2325), as soon as they show declarative order. Again, the truth of this assertion can be denied in a follow up of the type that's not true.
A: Der hat immer ein Glück./!
$\mathrm{He}$ has always a luck
B: Das stimmt doch gar nicht! 'That's not true.'

These tests show that it is $\mathrm{V}-\mathrm{C}$ movement in interaction with nonsyntactic means like intonation and certain lexical triggers that brings about an unambiguous interpretation. But neither of them can do this alone. This amounts to saying that clause type must be computed compositionally, much in the spirit of Zanuttini and Portner (2003).

\footnotetext{
${ }^{10}$ Hasegawa (1999) suggests an analysis where the verb on its way to C passes through the projection of the particle and thereby "picks up" its interpretative contribution. While such a solution may be viable for the particles (assuming that they are part of the clausal projection), I do not see how such an approach could capture the data with the indefinite determiner. There is no way in which the finite verb and the determiner could enter any formal relation, such that the verb could 'acquire' an exclamative clause type feature, bar ring the question in which sense an article could bear an exclamative feature. Although, see Bennis et al. (1998) for such a claim.
} 


\section{Ellen Brandner}

However, we will see in the next section that their treatment of V1E is also not without problems.

To summarize the findings from this section:

(i) it was argued that a pragmatic approach to V1E in terms of reinterpretation of a $\mathrm{Y} / \mathrm{N}$ question is not feasible.

(ii) during the discussion of the re-interpretation process, an asymmetry, or rather a hierarchy of clause types emerged with respect to their susceptibility to re-interpretation. The hierarchy can be stated as follows:

(30) a. wh-interrogatives resist any attempts of re-interpretation

b. Declaratives can acquire an exclamative/question reading while retaining their assertive character

c. Verb-initial structures are ambiguous with respect to their clause type and can be disambiguated only via

(i) intonation

(ii) lexical triggers

Before I will sketch an account of clausal typing that might cope with this hierarchy, I will discuss in some more detail the properties of V1E in order to bolster the claim a V1E is an exclamative - and only an exclamative.

\subsection{V1Es are exclamatives, not just exclamations}

In this section, I will show that V1Es have the same semantic-pragmatic properties as their better understood cognates, wh-exclamatives. I will base my discussion partly on the tests that have been developed in Zanuttini \& Portner (2003) and partly on another property that I argue to be relevant for exclamatives, namely the 'evaluative component'. It will be shown that this component can successfully distinguish exclamations from exclamatives. As will be discussed in section 4, it furthermore enables us to associate the clause type 'exclamative' with the nonassertion property that is characteristic for V1.

According to Zanuttini and Portner (2003), exclamatives are characterized by three constituting factors: factivity, scalar implicature, and the inability to occur in question-answer pairs. On the basis of these criteria, they develop various tests that distinguish exclamatives from other clause types. The next section shows that V1E pattern with wh-exclamatives in all these respects.

\subsubsection{Verb initial exclamatives and factivity}

The idea behind factivity as a test for exclamatives is that the co-occurrence of a wh-phrase and a factive predicate (which presup- 
poses the truth of the embedded proposition) leads to a contradiction. To resolve this contradiction, the hearer will interpret the utterance not as a question but as an exclamative, given that other possibilities (imperative etc.) are implausible. Embedding an exclamative under a factive verb like 'know' is therefore expected to result in an acceptable construction, whereas a non-factive matrix verb like 'wonder' cannot embed exclamatives but only interrogatives, see also Grimshaw (1979), Elliott (1974) and Abels (2007).

Since verb initial structures can never occur as embedded clauses due to the general ban on $\mathrm{V}-\mathrm{C}$ movement in subordinated contexts, I will simulate the embedding with a discourse where the 'embedding' verb occurs as a follow-up of an exclamative. Example (31) shows for an uncontroversial wh-exclamative that the acceptability of the follow-up clause depends on the factivity of the verb - as in complex clauses:

(31) A: Wie groß er geworden ist!

how big he become is

'How tall he has become!'

B1: Ich weiss - ich hab ihn auch gesehen.

'I know - I saw him too.'

B2: \#Das frage ich mich auch.

'I am wondering too.'

B3: \#Ich bin mir nicht sicher.

'I am not sure.'

(32) A: Wie groß ist er geworden?

how big is he become

'How tall has he become?'

B1: \#Ich weiss - ich hab ihn auch gesehen.

B2: Das frage ich mich auch.

B3: Ich bin mir nicht sicher.

As can be seen, the choice of the predicate in the follow-up patterns exactly ${ }^{11}$ with the predicates in the embedding test. If we apply this test to V1E, the same pattern emerges:

${ }^{11}$ In this case, the parallelism does not hold completely, since it is possible to have an embedded wh question under know. As is well known, know does not tolerate $\mathrm{Y} / \mathrm{N}$ questions in contrast to know + NEG. This shows already that the selectional restrictions of this verb are quite intricate. Furthermore, a response like I know * (it) (with the pronoun occurring obligatorily at least in German) is possible, as Klaus Abels points out to me. It is beyond this paper to go into a detailed discussion of the various readings of know. Suffice it to note that the reading of know in $(32 \mathrm{~B} 1)$, which is close to I noticed due to the follow up is not an adequate response to the question in (32 A). 


\section{Ellen Brandner}

(33) A: Spricht der ein Deutsch!

speaks he a german

B1: Ich weiß. Ich hab mit ihm gesprochen.

'I know. I talked with him'

B2: \#Das frage ich mich auch.

B3: \#Ich bin mir nicht sicher.

(34) A: Hat der sich aufgeregt!

has he REFL fussed

B1: Ich weiß.

B2: \#Das frage ich mich auch.

B3: \#Ich bin mir nicht sicher.

Example (35) shows that it is not possible to realize a negated factive verb in the follow-up clause, which would conflict with the factive presupposition as well.

(35) Spricht der ein Deutsch!- \#aber ich weiß es nicht so genau. speaks he a German but I know it not so exactly

'What a German he speaks - but I don't know exactly.'

As an intermediary result we can state that despite their apparent $\mathrm{Y} / \mathrm{N}$ question syntax, these V1E pass the factivity test for exclamatives.

Similarly, V1E pass the test for the presence of a scalar implicature. The scalar implicature captures the 'extreme degree' and unexpectedness component:

(36) Spricht der ein Deutsch! - \#Aber so gut ist es auch wieder speaks he a German But so good is it MP MP nicht

not

'What a German he speaks - but it is not really good'

(37) Er spricht ein gutes Deutsch! - Aber so gut ist es auch

He speaks a good German But so good is it MP wieder nicht MP not

'He speaks a good German - but it is not really good'

(37), as a declarative allows a modification/cancelling of the implicature, but not so the V1E. With respect to the inability to occur in question/ answer pairs, V1E again qualify as exclamatives. Like wh-exclamatives, V1E can never serve as an answer to a question: 
(38) A: Irgend etwas Besonderes passiert?

Something special happened?

B1: \#Hat der/Hans sich aufgeregt!

has he/John REFL fussed

B2: Der/Hans hat sich aufgeregt!

he/John has REFL fussed

(39) A: Und was passierte dann?

and what happened next?

B1: \#Hat der/Hans sich aufgeregt!

has he/John REFL fussed

B2: Dann hat der/Hans sich aufgeregt!

then has he/John REFL fussed

As illustrated with the $\mathrm{B} 2$ answers, the response becomes adequate if the declarative order is chosen, although the lexical content is the same in both clauses. We therefore have further evidence that the exclamative force is indeed tied to the V1 structure and not only to the lexical choice.

Finally, V1E pattern with 'normal' exclamatives in that they do not allow a follow-up question.

(40) Wie groß das Gebäude ist! \#15 oder 20 Meter?

How big the building is 15 or 20 meter

(41) Hat der sich aufgeregt! \#Und auch rumgebrüllt?

has he REFL fussed and also around-shouted?

'How he fussed! Did he also shout?'

(42) Spricht der ein Deutsch! \#Und auch (so) Französisch?

speaks he a German and also so French?

'How (well) he speaks German. Does he speak French the same way?'

To summarize, V1E show the same properties as wh-exclamatives with respect to the tests developed in Zanuttini and Portner (2003). The examples show furthermore that exclamatives are non-assertive: they do not update the Common Ground and it is not possible to refer to the truth-value and e.g. cancel it, cf. (35) This will become important below.

\subsubsection{Verb initial exclamatives and widening}

As already mentioned, for Zanuttini and Portner (2003), it is factivity occurring together with interrogative syntax that leads to an interpretational conflict. This conflict is resolved by manipulating the meaning of the question. Recall that in a Hamblin/Karttunen style semantics for interrogatives, the meaning of a question is the set of its (true) answers. This set is enlarged in exclamatives by an operator called $R_{\text {widening. If this }}$ operator applies, the set includes more elements than the answer-set. Instead of having e.g. p1, p2, and p3 in the set, there is even p4 (and may 


\section{Ellen Brandner}

be p5). This enlargement is at the base of the exclamative interpretation. The crucial point for the discussion here is that in their view, the semantics of exclamatives is based on the semantics of questions containing a wh-phrase, see also d'Avis (2001). If widening is a constitutive property of an exclamative, exclamatives based on $\mathrm{Y} / \mathrm{N}$ questions are in need of a different treatment - because these do not contain a wh-phrase by definition.

In their (2003) paper Zanuttini and Portner discuss how V1E could be captured by invoking widening nevertheless. They suggest that in these cases, widening applies to truth values. Assuming that a $\mathrm{Y} / \mathrm{N}$ question has only a singleton set as its denotation, widening extends this set by adding the proposition with the opposite truth value. The example they discuss is from Italian and contains a pleonastic negation:

(43) No ga-lo magnà tuto!

NEG has-S.CL eaten everything

'He has eaten everything!'

The contrast between the implied and the expressed event ('the child does normally not eat everything' and 'this time the child ate everything') is the noteworthy fact expressed in the exclamative. However, according to this line of reasoning a sentence like (5), repeated here for convenience, should imply that the person referred to does normally not fuss.

(44) Hat der sich aufgeregt!

has he REFL fussed

'How he fussed!'

But this is not how we interpret the sentence. This sentence can also be used if the person in question fusses quite often. So it is obviously not the opposite event that is taken into consideration if one utters (44). ${ }^{12}$ If it were, we would expect the following sentences with achievement verbs to be possible:

(45) a. *Haben die (nicht) geheiratet! have they (not) married (... although I thought they would never marry)

b. *Hat der den Gipfel (nicht) erreicht! has he the peak (not) reached (... although he normally has to give up quite early)

The fact that these examples are out shows that Zanuttini and Portner's analysis of V1E cannot be correct. Note, that there is nothing wrong with

\footnotetext{
${ }^{12}$ Furthermore, since widening in this case can only add the same proposition with the converse truth value, its application reduces basically to unexpectedness, i.e. the surprise component. However, as is shown by Zanuttini and Portner (2003) themselves, this is not a necessary property of exclamatives.
} 
an interpretation as suggested by Zanuttini and Portner (2003). It is perfectly normal to consider the opposite event, as indicated by the follow-ups. Nevertheless, the sentences are bad.

\subsubsection{The degree component}

Note that the ungrammatical examples in (44) are perfectly acceptable as soon as a modifying adverb is added:

(46) a. Haben die aufwändig geheiratet!

have they costly married

'How costly they have married!'

b. Hat der den Gipfel schnell erreicht!

has he the peak fast reached

'How fast he has reached the peak!'

The adverbs that render exclamatives with achievement verbs acceptable introduce a degree cpmonent. ${ }^{13}$ Moreover, all examples of bare (i.e. adverbless) V1E exemplified so far include verbs with an inherent degree component. Verbs with a degree component like aufregen 'to fuss' can be modified by the degree element sehr 'very' whereas typical achievement verbs like heiraten 'marry' cannot. I assume here in accordance with Doetjes (1997), Kennedy (1999), Corver (1990), and Neeleman et al. (2004) that gradable lexical items have an additional degree-phrase, which may host degree words like so, very, much, more, extremely, but can also be phonetically zero: ${ }^{14}$
a. Er hat sich sehr/extrem aufgeregt. he has REFL extremely fussed 'He has fussed extremely!'

A minimal pair that shows the effect of the presence/absence of a gradable element quite convincingly is the following:

${ }^{13}$ Note that so called 'degree achievements', s. Dowty (1979:88 90) like cool, lengthen, shrink etc. are fine in exclamatives:

(i) ist der Pullover geschrumpft!

is the sweater shrunk

'How the sweater has shrunk!'

As expected, this ability is lost as soon as the degree is spelled out via a measure specification (e.g. 2 centimetres) since then the predicates become telic. Thanks to Klaus Abels for this example.

${ }^{14}$ Since I am concerned here with the interaction of V C movement and the exclamative interpretation, I will not go into a detailed discussion on the syntactic status of these elements. For the purposes here, it is sufficient that their presence is a pre condition for the exclamative interpretation. 
(48) a. *Ist der gegangen!

Is he gone

b. Ist der gerannt!

Is he run

'How he has run!'

If a manner component is present in the motion verb, the exclamative is possible. Similarly, semelfactives like laugh and cough can occur in exclamatives and again, it is not implied that the person does normally not laugh or cough. What is relevant is the intensity, i.e. the degree in a broader sense:

(49) a. Hat der gelacht!

has he laughed

'How he has laughed!'

b. Hat der gehustet!

has he coughed

'How he has coughed!'

Finally note that adding the 'exclamative particle' aber does not save an exclamative with an achievement verb:

(50) *Haben die aber geheiratet! have they PRT (=but) married

The examples show that the crucial property of V1E is obviously not the construction of opposite events, but that a gradable element is present. Under this perspective, theories that foreground the degree component in the analysis of exclamatives, like e.g. Castroviejo (2006) and Rett (to appear) capture the data more adequately. In the following, I will therefore assume that the degree component is (one of) the relevant factor(s) for the exclamative interpretation.

The obligatoriness of the degree component also offers an explanation for the occurrence of the indefinite article with mass nouns in exclamatives. The indefinite article turns the mass noun reading into a kindreading, e.g. if somebody speaks 'a (kind of) German', this implies that other kinds of German exist as well (good German, bad German, horrible German etc.), which can be ordered along a scale. For the sake of concreteness, I will here simply assume that the presence of the indefinite article is a reflex of a structure containing an (phonetically empty) ${ }^{15}$

${ }^{15}$ Note that the adjective may be overt:

(i) Spricht der ein gutes Deutsch! speaks he a good German! 'How fantastic his German is!'

If the adjective is overt, the sentence can also be understood as a question whereas a zero adjective allows only the exclamative interpretation. I will come back to this difference in section 3.4 . 
adjective, and therefore the examples containing a mass noun with an indefinite determiner trigger the exclamative interpretation. Since I am concerned here with the verb movement in V1E, I will refrain from a more precise characterization. ${ }^{16}$

This section discussed the shortcomings of the notion of widening and it was shown that it is preferable to adhere to degree as being constitutive for exclamatives. Widening, if applied to V1E as suggested by Zanuttini \& Portner (2003), delivers only the same type of event with a reversed truth value as the topic of the exclamation. However this does not capture the right interpretation.

\subsubsection{The evaluational attitude component}

In the literature, it is often suggested that exclamatives refer somehow to an 'extreme degree' - a notion which is hard to define in any precise way. Equally hard to define is another characteristic that is often attributed to exclamatives, namely the surprise component or more general 'emotional affectedness'. Because of the vagueness of these notions Zanuttini and Portner (2003) dismiss them and try instead to subsume these characteristics under their notion of widening, resp. scalar implicature. This might be possible for the notion of 'extreme degree"17 but not for 'emotional affectedness'. In this section I will sketch an alternative view on these rather imprecise notions and connect it to the non-assertive interpretation (and as will be shown below to the non-assertive syntax) of exclamatives.

Affectedness and emotional involvement is not a distinguishing feature of exclamatives. Declaratives and interrogatives can involve these components as well. What seems to be a promising way to go is to integrate exclamatives into the theory of 'expressives' as developed in Potts (2005, 2007), see Castroviejo (2008) for a first attempt. Since I am concerned mainly with the syntax of V1E, however, I will not discuss these issues and stick to an informal description of the relevant characteristics.

What seems to be crucial for exclamatives is the 'evaluative' component, i.e. what is termed the emotional attitude towards the proposition, e.g. by Zaefferer (2001). This characteristic property can be distinguished from the emotional affectedness that can be found in other sentence types by a simple test.

Let us consider an example of an emotional declarative sentence first. Suppose a girl who is waiting for her grandparents suddenly hears a car which she wrongly takes for her grandparents' car. She utters (51). Emotional affectedness is clearly involved here, but there is no evalua-

\footnotetext{
${ }^{16}$ See Brandner (2008) for more discussion.

${ }^{17}$ But see Sæbø (2006) for a critical view.
} 
tional attitude expressed, as can be witnessed from the (in-)adequacy of the responses (e.g. from the parents) in $\mathrm{B} 1$ and $\mathrm{B} 2$ :

(51) A: Sie kommen!

'They come!'

B1: \#Find ich nicht

Find I not

'I don't think so'

B2: Stimmt nicht.

'This isn't true'

If the parents recognize that the child mistook the approaching car, the sentence B2, which challenges the truth of the sentence in A, is an adequate response. $\mathrm{B} 1$ on the other hand, which expresses disagreement, is not. So, although the utterance in (51) is an exclamation and although emotional affectedness is present, it is not possible for the hearer to either agree or disagree.

In the case of those sentences that have been classified as exclamatives, agreement or disagreement is the natural and the only licit reaction: ${ }^{18}$

(52) A: Spricht der ein Deutsch!

speaks he a german

B1: Das find ich jetzt gar nicht. Find ich auch.

that find I now PRT not Find I too

'I don't agree at all' 'I find that too'

B2: \#Das stimmt doch gar nicht!

'This isn't true!'

(53) A: Hat der sich aufgeregt!

has he REFL fussed

B1: Finde ich nicht

Find I not

'I don't think so.'

B2: \#Das stimmt doch gar nicht!

'This isn't true!'

The fact that disagreement is the adequate response to an exclamative, shows that the hearer can reject the speaker's evaluation but not the truth of the proposition.

${ }^{18}$ Note that this test excludes also the following sentences from the class of exclamatives:

(i) Dass die U Bahn noch fahrt! embedded declarative that the subway still runs

(ii) Mit wem der sich so rumtreibt! with whom he REFL so around roves

embedded wh interrogative

There is no way to respond to these utterances with something like I don't think so (e.g. Find ich nicht 'I don't think so' or Stimmt doch gar nicht 'This isn't true') but again their truth value can be denied. 
Thus, besides factivity, non-assertiveness, and the degree component, there seems to be another constitutive property for exclamatives, namely 'evaluation', i.e. the speaker has an attitude towards the degree expressed and judges it in some way or other. The hearer can agree or disagree with this evaluation. And crucially, this is the only adequate reaction. If we now reconsider those cases which are interpreted as exclamations but have the structure of a declarative, we see that both reactions are possible. The assertion is still accessible, see B2 - although an expressive/ evaluative component is present, too.
A: Der hat sich aber aufgeregt./! he has REFL PRT (= but) fussed
B1: Finde ich nicht Find I not
B2: Das stimmt doch gar nicht! 'This isn't true!'

\subsection{Summary}

The results of the previous discussion concerning clause types and their properties are summarized in table 1 . The $\%$-sign is meant to indicate that a degree and/or evaluation component is neither excluded nor required:

Table 1. Clause type properties

\begin{tabular}{lcccc}
\hline & factivity & assertion & degree & evaluation \\
\hline Declarative (54) & & yes & $\%$ & $\%$ \\
V1E (53) & yes & no & yes & yes \\
Wh exclamative & yes & no & yes (via how) & yes \\
Y/N question & no & no & $\%$ & no \\
\hline
\end{tabular}

Recall that the evaluation component in a V1E is not necessarily overtly expressed by some overt lexical material. It is sufficient that a gradable element is present in the clause, even if its presence can only be inferred via the syntactic surrounding, as in the case of the indefinite article with mass nouns, cf. (53). This case shows quite clearly that the interpretative process indeed must recur to semantic-pragmatic inference procedures. As was mentioned in foot note 11, the adjective may be overt in these constructions but then the sentence is again ambiguous between the question and the exclamative reading. If the adjective is empty, only the exclamative reading is available. The reason might be that the question reading aims at the adjective. Does he speak a good German requires an answer either of Yes, it (his German) is good or No, it's quite bad but it can never refer to the ability of speaking German alone, i.e. via

\footnotetext{
${ }^{19}$ Rhetorical questions probably contain an evaluative component too, but I will not discuss this here.
} 
the adjective it is presupposed that he speaks German. However, without an overtly expressed adjective, there is no basis for this type of question/ answer pair. Therefore, the only reasonable interpretation is the exclamative one, since this is the only one that is also compatible with a verb-initial structure. Without going into a detailed pragmatic analysis, it is obvious that the lexical triggers which force one of the readings do not encode the exclamative clause type themselves. They initiate a pragmatic inference process which selects the relevant interpretation via a process of elimination - crucially, this is not an indirect speech act, recall that these sentences are ungrammatical as $\mathrm{Y} / \mathrm{N}$ questions.

Since intonation is likewise not an effectual clause typing device, we can conclude that verb-initial structures are indeed syntactically underspecified.

The next question to address is therefore how V-C movement can lead to these different sentence types although the syntactic device is the same. I have added $\mathrm{Y} / \mathrm{N}$ questions in table 1 in order to illustrate in which respects they pattern with V1E and in which they differ. The table shows that the only component they share is the non-assertive property. They differ in factivity and the degree as well as the evaluative component. These latter two components may occur in $\mathrm{Y} / \mathrm{N}$ questions (is the movie really so boring?), but these properties are clearly not constitutive for $\mathrm{Y} / \mathrm{N}$ questions in the way they are for exclamatives. In the next section, I will argue that the non-assertive property is in fact the clue to understand why $\mathrm{Y} / \mathrm{N}$ questions and V1E share the same syntactic structure.

\section{Typing and V1 Structures}

\subsection{Is every clause typed?}

In the generative literature, clause types are generally represented by syntactic features that reside in the C-layer of the clause. In embedded clauses, the clause type is encoded in the complementizer (e.g., that vs. if). In main clauses, the clause type feature is responsible for verb movement (if it is strong) and also for wh-movement in the case of wh-questions. Adger (2003), for instance, assumes that the C-head of a given English clause either contains a DECL(arative) or a Q(uestion) feature. The difference between the two is that the Q-feature is strong whereas the DECL feature is weak. The strong Q feature must be checked overtly in the syntax, thus triggering $\mathrm{T}-\mathrm{C}$ movement. Since the DECL feature is weak, there is no overt movement.

In principle, the same strategy could be used for the V1 structures above with one $\mathrm{C}$-head being labeled as $\mathrm{Y} / \mathrm{N}$ question $(\mathrm{Q})$, and the other one as exclamative (EXCL). Both features are strong so that verb movement can take place overtly. Since different features are involved, different interpretations arise. 
Note, however, that in order to capture the different word order of wh-exclamatives and V1E, the clause type feature EXCL must have two different values for strength. In case of V1E it must be strong, and in case of wh-exclamatives, where the verbs stays in a lower position, it must be weak. Since clause type features cannot be both strong and weak, the theory cannot account for the empirical fact that exclamatives with and without V-C movement exist. ${ }^{20}$

With respect to verb-initial structures, the syntactic structure itself gives no hint on the clause type as long as it is not disambiguated via a suitable intonation. Thus, the clause type feature can be fixed only after syntax, so to speak. Theories based on the (sometimes abstract, i.e. phonetically empty) presence of a distinct syntactic clause type feature/ operator for each sentence type would have to assume that all the possible interpretations (clause types) of a construction are listed, which is not how a clausal typing theory should work, see Reis (1999), Zanuttini and Portner (2003) and Portner (2004) for similar objections. Whatever technical execution of a feature based approach to clause typing is chosen, the core assumption is always that the information about the clause type is part of the syntactic representation. But such a syntactic implementation of clause type makes it not only impossible to understand the structural underspecification of $\mathrm{Y} / \mathrm{N}$ interrogatives and exclamatives, but also fails to account for the different susceptibility to re-interpretation of wh-interrogatives and declaratives discussed in section 3.2.

Putting aside for the moment (the commonly assumed) V-C movement in declaratives in $\mathrm{V} / 2$ languages, the suggestion I want to make here is that clause type features are not part of the syntax. Instead of features like $Q$ and DECL, the syntax proper divides merely between assertive and non-assertive clause types - and this information is associated with $\mathrm{V}-\mathrm{C}$ movement:

$$
\mathrm{V}-\mathrm{C} \text { movement signals a non-assertive clause type }{ }^{21}
$$

${ }^{20}$ Note that the same problem arises for Zanuttini and Portner (2003) who assume that a factivity feature which is situated in the $\mathrm{C}$ layer prohibits $\mathrm{V} \mathrm{C}$ movement in the case of wh exclamatives. They suggest that the verb targets a different $\mathrm{C}$ layer in this case, which is present in wh exclamatives, but they have to admit that there is no independent evidence.

${ }^{21}$ It is a commonplace that in the classical V/2 languages (Germanic with the exception of English) the verb moves to $\mathrm{C}$ in all root clauses, including declaratives. This should block the assertion interpretation according to the proposal above. I assume that the obligatory movement of "non" operator elements, like e.g. subjects, stage topics, and even expletives, 're establishes' the neutral declarative interpretation, see Brandner (2004) for further elab oration. A reason for this deviant behavior of $\mathrm{V} / 2$ might be related to the observation that $\mathrm{V} / 2$ languages (except Icelandic) do not allow the verb to be overtly realized in $\mathrm{T}$, even in embedded clauses. Whatever the reason for this restriction is, one could argue that $\mathrm{V} / 2$ languages since the $\mathrm{T}$ level is not available must 'simulate' the TP layer on the C level. As soon as a wh operator moves there, the V/2 languages behave like 'normal' non V2 lan guages. Another possibility within a cartographic approach is to assume that the verb in 'neutral' declaratives targets a lower position within the $\mathrm{C}$ layer, i.e. a finer grained refor mulation of the asymmetric approach to V/2 as in Travis (1984) and Zwart (1993), extended to the operator/non operator distinction. 
Structures without V-C movement, which can be taken as the default or unmarked structures, are interpreted as assertive. Note that (55) does not make any predictions about which clause type the structure will be associated with it in the end. It merely formulates the restriction that $\mathrm{V}-\mathrm{C}$ movement excludes assertive readings.

There is one clause type, however, which is unambiguously determined by an additional syntactic operation, namely wh-questions. Movement of a wh-phrase to Spec-CP leads to an unambiguous structure. Here, the resulting spec-head configuration can be taken as an instance of typing in the classical sense: the wh-element in Spec-CP provides the head of the clause (realized by the finite verb in C) with a wh-feature and thus the whole projection carries a syntactic wh-feature as well. This amounts to saying that only wh-questions are syntactically typed whereas the other clause types are syntactically underspecified. ${ }^{22}$

If this assumption is correct, we have an explanation for the asymmetry with respect to reinterpretability between wh-questions on the one hand, and verb-initial structures and declaratives on the other:

(56) (i) Wh-questions are syntactically typed and therefore immune to 'reinterpretation'

(ii) All other clause types are not syntactically typed no $\mathrm{V}-\mathrm{C}$ movement $\rightarrow$ assertive, via default assignment of declarative

$\mathrm{V}-\mathrm{C}$ movement $\rightarrow$ underspecified, crucially non-assertive

As has been discussed in section 3.3., there is a further difference between declaratives and V1 structures: while declaratives preserve their assertive meaning component if they undergo reinterpretation (rising declaratives, exclamations), i.e. the declarative clause type is syntactically still present, i.e. there is no cancellation, there is no evidence for any such relation between an 'underlying' $\mathrm{Y} / \mathrm{N}$ question and a V1E. For this reason, I assume that there is no syntactic specification in the first place and that therefore, the actual interpretation of these underspecified verb-initial structures must resort to other, non-syntactic means.

\subsection{What is a clause type? ${ }^{23}$}

Given the discussion above, it is a legitimate question whether clause type is a primitive notion at all or whether it is an 'artifact' under which other properties are subsumed.

Recall that Gunlogson (2001) has shown that the assertive property is not cancelled in rising declaratives, but rather shifted from the speaker to the hearer. By using a declarative, the speaker commits himself to the

\footnotetext{
${ }^{22}$ Note that this is in contrast to Cheng's (1991) clausal typing hypothesis which requires that every clause needs to be typed.

${ }^{23}$ This section relies heavily on discussions with Ingrid Kaufmann.
} 
truth of the relevant proposition; by using a rising declarative, the speaker assumes that the hearer is 'knowledgeable' about the truth value, i.e. the knowledgeability is shifted from the speaker to the hearer. In both cases the clause type is related to the knowledge about the truth value of a proposition $\mathrm{p}$ on side of one of the speech act participants (SAPs). Gunlogson is mainly concerned with modeling the contribution of the various clause types to the discourse. I am concerned here with the question how clause types can be represented in a more flexible way such that the observation in (56) can be captured also on a syntactic basis. The idea that the different states of knowledgeability of the speaker/addressee might open an interesting way. Without introducing here the technical machinery in Gunlogson's approach, we can take it as the basis for distinguishing the different clause types and their corresponding speech acts. The suggestion is that clause types can be modeled by differentiating between the knowledge states of the SAPs. Consider the various possibilities that arise if we cross-classify the possible 'knowledgeabilities' of the SAPs:

Table 2. Possible combinations of SAPs' knowledge ability

\begin{tabular}{ccc}
\hline & Speaker & Addressee \\
\hline (i) & + & - \\
(ii) & + & + \\
(iii) & - & + \\
(iv) & - & - \\
\hline
\end{tabular}

The first combination corresponds to a plain assertion, i.e. $\mathrm{S}$ knows $\mathrm{p}$ and assumes that A doesn't know p. By uttering $\mathrm{p}$ via a declarative clause, $\mathrm{S}$ updates the common ground. This is the unmarked case which corresponds to the equally unmarked declarative clause type in syntax.

The reverse pattern is given in (iii). $\mathrm{S}$ does not know about $\mathrm{p}$, but assumes that A knows about $\mathrm{p}$. The interrogative clause type with a question interpretation naturally corresponds to this combination. ${ }^{24}$ About (iv) I do not have to say anything here, beside the mere speculation that e.g. imperatives could be represented by this configuration. In imperatives, truth values demonstrably do not play a role at all, which is captured by the negative specification for both $\mathrm{S}$ and $\mathrm{A}$.

Finally, let us turn to (ii), where both $\mathrm{S}$ and $\mathrm{A}$ are knowledgeable - at least $\mathrm{S}$ assumes that $\mathrm{A}$ knows about $\mathrm{p}$. This combination expresses the factivity property that is assumed by Zanuttini and Portner (2003) as being constitutive for an exclamative. But instead of assuming that there is a 'factivity' layer in the syntactic tree, the suggestion here is that it is the

\footnotetext{
${ }^{24}$ Alternatively, one could assume that the knowledgeability of A is not known by S. This is probably the normal case in a question situation.
} 
'knowledgeability' of A that is expressed syntactically. Not in the sense of a specific functional projection; rather the configuration that arises via $\mathrm{V}-\mathrm{C}$-movement is the syntactic correspondent to the situations in which $\mathrm{A}$ is knowledgeable, i.e. A + .

Very much in line with the reasoning in Zanuttini and Portner (2003), the exclamative interpretation arises via an interference process, because neither the specifications relevant for assertions (A should be minus) nor those relevant for questions ( $\mathrm{S}$ should be minus) are met and thus only an 'expressive' interpretation, i.e. an interpretation which is 'beyond truth values', is adequate.

The main idea is thus that the various clause types correspond to the different combinations of the knowledgeability states of S and A. $\mathrm{V}-\mathrm{C}$-movement comprises those cases where A is knowledgeable. The next section will be concerned with the syntactic implementation of this idea.

\subsection{The mechanism of 'clausal typing'}

Following common assumptions about the general architecture of the clause, I will assume that the VP layer characterizes the event that is the core of the clause, that TP anchors the event variable in time such that we get a proposition, and finally that the CP-layer as the root node - which has direct access to discourse - is responsible for the mapping to illocutionary force. Since the pioneering work by Wechsler (1991) it is a widespread assumption that $\mathrm{V}-\mathrm{C}$ movement is connected to illocutionary force, for a more recent discussion under a semantic perspective see Truckenbrodt (2006). As already mentioned in 4.1., a common implementation of this connection is to posit a syntactic feature in the C-domain; however, the result of the discussion in the previous section was that this implementation cannot account for the observed flexibility.

If we assume now that the 'trigger' for verb-movement is not a pre-defined clause type feature but rather to mark the knowledgeability of the addressee, then verb movement serves to single out the configurations (ii) and (iii) of table 2, and we can replace 'non-assertiveness' with the more precise characterization in (57):

(57) Clauses with V-C movement correspond to A+

Since verb movement to $\mathrm{C}$ reflects only $\mathrm{A}+$, the structure is compatible with $\mathrm{S}+$ (exclamative) as well as $\mathbf{S}-$ (interrogative), thus the value of $\mathbf{S}$ is left unspecified at this step of the derivation. This situation reflects the ambiguity of verb-initial structures, signified by the bold type of the values that are compatible with this structure. Only non-syntactic means can disambiguate between a $\mathrm{S}+$ or a $\mathrm{S}-$ interpretation, indicated here via the intonation arrows: 


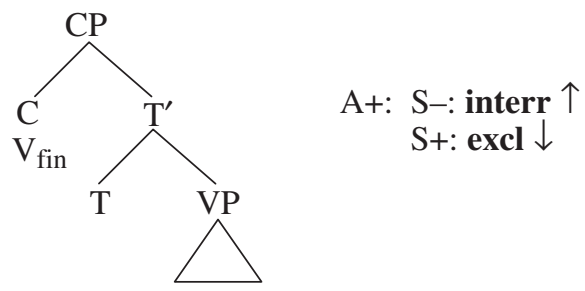

If $\mathrm{A}$ is - , as in declaratives, the verb stays in $\mathrm{T}$, and the clause is interpreted as being assertive.

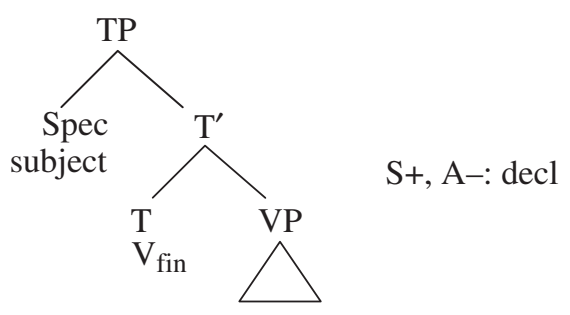

Note that the verb moves to $\mathrm{T}$ for independent reasons, namely in order to check its tense-feature. Thus, movement to $\mathrm{T}$ is not related to clause typing. The specification $[\mathrm{S}+, \mathrm{A}-]$ is the default option, corresponding to a situation where $\mathrm{S}$ utters $\mathrm{p}$ in order to update the CG for a (not knowledgeable) A. Syntactically, this is in line with the well-observed fact that in many languages, the declarative clause type is not marked at all. I assume that the default specification comes about if the syntactic derivation stops at the TP-level - which is possible because all other independent syntactic requirements (Tense, Agreement, Case) are met. The sentence will be interpreted as a plain assertion, i.e. a declarative. As we have seen above, this clause type is susceptible to overlay-interpretations. This can directly be attributed to the fact that no syntactic typing procedure has taken place and that the structure is interpreted as an assertion merely by a default rule.

For wh-questions, it has been argued above that this is the only case where syntactic typing is at stake, namely via operator movement to Spec-CP. For concreteness, I will adopt a suggestion by Rizzi (1996) in which he proposes that an operator in a specifier position can endow the head of the respective phrase with this feature. This can be rephrased now as follows: Since the wh-operator introduces the question interpretation via lexical means, the specification of $S$ as + would lead to a contradiction; the wh-feature in Spec-CP restricts the value of $\mathrm{S}$ to -. Therefore, these structures are unambiguously interpreted as interrogative. Since this value is determined by a syntactic operation, nonsyntactic means like intonation or lexical triggers cannot alter its specification. 
(60)

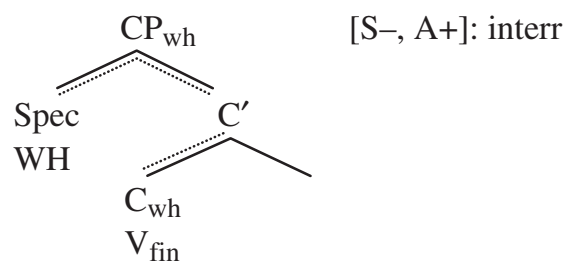

The alternative to a feature checking mechanism sketched here opens a way to deal with the systematic ambiguity of verb-initial structures. The next step is to develop a precise theory about how the disambiguating devices exactly interact with these underspecified structures in the pragmatic domain. But this is surely beyond the scope of this paper and has to wait for future research.

\section{Wh-exclamatives}

In this final section, I will briefly discuss how wh-exclamatives could fit into the picture above. I can only touch upon some issues; two of them will be dealt with: (i) 'standard' wh-exclamatives with no verb-movement and (ii) wh-exclamatives with verb-movement in German and Dutch.

Let us first consider (ii). In contrast to English we find instances of exclamatives in German where V-C movement occurs together with a fronted how or what, in Dutch only what ${ }^{25}$, cf. Corver (1990), Bennis (1998). These can be used as an alternative to bare verb-initial exclamatives:

(61) a. Wie bist du groß geworden!/ (?) how are you big become

b. Was bist du groß geworden!/ *? what are you big become 'How tall you became!'

\footnotetext{
${ }^{25}$ I cannot offer an explanation why 'how' is possible in German and not in Dutch, but it seems obvious that both clauses are structurally identical in the exclamative reading. One could speculate that 'how' is in this configuration an alternative 'PF realization' of the unmarked 'what', both being able to correspond to the degree component. This is remi niscent of the scope marking construction in German, where the neutral form 'what' can be replaced with a copy of the wh phrase in the embedded clause:
}

(i) was/ wen glaubst du [wen er getroffen hat] what/ whom believe you whom he met has 'Who do you think that he met'

This interchangeability seems to be restricted in (Standard) Dutch, but see Barbiers et al (2008) for a discussion of its occurrence in various dialects. See also Vangsnes (2007, 2008), on related (surface) variation on measure and kind phrases in Scandinavian dialects. 
(62) a. Wat is ze mooi!

what is she nice

'How nice she is!'

b. *Hoe is ze mooi

how is she nice

First note that (61a) is ambiguous between an exclamative and an interrogative reading - if clues from intonation are lacking. Although the interrogative reading is only possible with how being interpreted as a manner adverbial; possible answers would be 'by eating enough pasta' or 'by consuming steroids', etc. ${ }^{26}$ Nevertheless, it is important for the discussion here that this reading is available: this interrogative reading is an instance of (60) with syntactic typing via the wh-phrase in the Spec$\mathrm{CP}$. This is possible since how is lexically ambiguous between being the wh-counterpart of a manner adverbial and the degree element 'so (much)'. The most pressing question is how the exclamative reading may arise at all in (61a) - and of course also in (61b) which has only exclamative interpretation.

The answer lies in the nature of the element was/wie. Let us assume that these elements are the wh-counterparts to the degree element 'so', as seems quite natural. Recall from section 3.3.3. that the degree component is a constitutive part of any exclamative. In bare V1E, the degree element must be inferred since there is no overt realization of it in the clause. In (61), although having basically the syntactic structure of a V1E, the degree element is overtly realized in the shape of was/wie. We can take them as another disambiguating device, since they do not add any further content to the exclamative and there is no interpretational difference between a V1E with and without these elements.

The question then is what are the syntactic properties of these elements and can these help us to understand why (61) is possible at all. Recall that the typical property of wh-exclamatives is that they do not exhibit V-Cmovement. As assumed above, was/wie correspond to 'so', the typical degree element, they are merely heads from a phrase structural point of view, see Neeleman et al (2004) for justification. As heads, they cannot occupy the Spec-CP position, therefore no spec-head agreement can arise and they cannot deliver their wh-specification to the head of the clause, i.e. question interpretation is impossible. This is the first part of the answer why there is no interrogative reading in (61). ${ }^{27}$ But the next question is, how are these elements integrated into the structure?

For a head-element, the only possibility to surface in the left periphery of a root clause is that it adjoins in a clitic-like fashion to

\footnotetext{
${ }^{26}$ Therefore the parenthesis because this is an entirely different interpretation with no relation to 'degree' and exclamative whatsoever.

${ }^{27}$ Manner how of course has phrasal status.
} 
the finite verb, being located in $\mathrm{C}^{0}$, such that we get a configuration as depicted in (63):

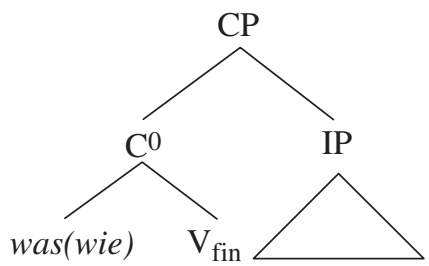

As a clitic, the wh-element is likewise not in a spec-head configuration with the finite verb. Nor does it head its own projection which could project the wh-feature to the clausal projection. Therefore, the configuration in (63) cannot provide the clause with a wh-feature - despite the wh-nature of the fronted element. For this reason, the questioninterpretation does not arise in this configuration, instead the exclamative - as the only alternative interpretation, due to $\mathrm{V}-\mathrm{C}$ movement. Let us see by which facts this analysis is supported.

Evidence that was is head-like in exclamatives, is provided by the following facts, discussed in Trissler (2005): was cannot be coordinated with another wh-phrase, (64a) nor can it be long-extracted from an embedded clause, (64b):

(64) a. *Was und wie oft der Otto seinen Kindern hilft! what and how often the Otto his children helps

b. *Was glaubst du, dass der Otto seinen Kindern hilft what think you that the Otto his children helps

These data find a natural explanation if was is a head in exclamatives: there is no head-movement crossing a CP, (64b); and heads cannot coordinate with XPs, as in (64a). ${ }^{28}$

German (and also Dutch) obey strictly the V/2 constraint in that only maximal phrases can move to the left edge of root clauses. Unlike Northern Norwegian, see Westergaard \& Vangsnes (2005) for wh-questions that do not trigger V/2, German and Dutch do not allow heads to end up in a left peripheral position in root clauses. ${ }^{29}$ But we have seen that 'what' nevertheless behaves like a head in all relevant respects. So the only possible structure is to cliticize the element to the finite verb in initial position, as in (63). As a clitic, we expect that it cannot bear stress; and this is indeed the case:

\footnotetext{
${ }^{28}$ Note that in case was is replaced by wie, according to the pattern in (61), the outcome is grammatical, but only with the interrogative interpretation where wie has a manner reading.

${ }^{29}$ However there is evidence that this possibility exists in embedded clauses, see Bayer \& Brandner (2008).
} 
(65) a. *WAS bist du gross geworden!

what are you big become

b. *WIE bist du gross geworden!

how are you big become

In contrast, how with the manner-reading as in (61a) can be stressed without problems, as any fronted wh-phrase can - in an interrogative. However, the particle-like element in (61) and (65), corresponding to 'so', does not have phrasal status, thus cannot occupy Spec-CP and cannot be stressed/focused.

A last piece of evidence that was/wie must be analyzed as a clitic in this construction, is that a 'prototypical' wh-exclamative with the verb in its base position is not possible - at least highly marked:

(66) ${ }^{? ?}$ was du gross geworden bist! ${ }^{30}$

what you big become been

'How tall you became!'

The awkward status of (66) follows straightforwardly since there is no adequate clitic host in $\mathrm{C}^{0}$. The only other possible structure for this clause would be to merge the head was directly into the $\mathrm{C}^{0}$ position - a possibility which is in principle given since degree-was starts out already as a head, see above. This would avoid the ban against empty $\mathrm{C}^{0}$ and would thus correspond in a sense to the Northern Norwegian non-V2 questions $^{31}$ - however, I have to leave open what consequences this would have for the grammar of German.

In sum, the alternative realization of a V1E with a clitic was/wie does not challenge the proposal of the previous section: the finite verb is in $\mathrm{C}^{0}$ but this configuration alone is not decisive for the exclamative interpretation, as we have seen in the preceding sections. Adjoining was (corresponding to so) in clitic-like way to the finite verb yields an unambiguous interpretation, because in this case, the degree component is overtly realized. The cliticization renders the interrogative interpretation impossible since the wh-feature cannot be transferred to the head of the clause, i.e. there is no typing configuration. The same holds for wie if it corresponds to the degree-element. Since wie is ambiguous between

\footnotetext{
${ }^{30}$ Trissler judges this example as good, as well as H. G. Obenauer (p.c.). According to my intuitions and several others, it is out. A string search on the internet for 'was du schon bist' (verb end) yielded 10 results whereof 8 were the (identical) citation of a sentence from an old fairy tale. In contrast, 'was bist du schon' (V C) had 8.780 hits. The sentence in (66) occurred 5 times on the internet (two of them in linguistic papers!). With fronting of the verb, there were more than 51.000 hits. I am aware that there are a lot of interfering factors in internet searches like this (written vs. spoken language etc.) and that one should be careful with such 'results', but I think the ratio in the occurrence of the two versions is nevertheless telling. Interestingly (66) is better if was is interchanged by wie (14.100). A check of the first 50 results revealed that about half of the hits were embedded questions.

${ }^{31}$ Recall that in Northern Norwegian, non V2 questions are only possible with wh items that do not have phrasal status.
} 


\section{Ellen Brandner}

degree and manner reading, the surface string wie $+\mathrm{V}_{\text {fin }}$ can additionally be interpreted as a question, since in this case, wie moves as a phrasal XP to Spec-CP, giving rise to a typing configuration.

The last considerations that I want to make is about wh-exclamatives with an initial wh-phrase and the verb in its base position, i.e. those constructions that are taken to be the 'prototypical' case of an exclamative. These also seem to pose a problem for the theory developed in section 4: because the lack of $\mathrm{V}-\mathrm{C}$-movement goes along with an $\mathrm{A}-$ interpretation, an exclamative reading should be unavailable. But they clearly are exclamatives. On the other hand, the theory so far makes the correct prediction that these sentences cannot be interpreted as interrogatives because the lack of $\mathrm{V}$-C-movement prohibits a spec-head configuration with the wh-phrase and thus the precondition for syntactic typing is not given.

However, since I tied the $[\mathrm{S}+, \mathrm{A}+]$ interpretation to $\mathrm{V}-\mathrm{C}$-movement, the problem of course remains how these sentences can get an exclamative interpretation at all. One way to approach this problem is to reconsider the idea that wh-exclamatives are embedded clauses with an elided matrix predicate, i.e. reviving in a sense the 'performative hypothesis' (Ross 1970). There are several facts that make such a solution plausible: In Southern German dialects, which allow for a doubly filled comp (DFC), a complementizer is inserted after the whphrase:

(67) Wie schön dass die ist!

how pretty that she is

'How pretty she is'

The same is true for Paduan, as reported in Zanuttini \& Portner (2003) who take the complementizer che in this case as a spell-out of the factivity-operator. ${ }^{32}$

(68) Cossa che-1 magnava!

what that-S.CL eats

'What things he eats!'

In Catalan, there is evidence that the structure of a wh-exclamative corresponds to that of relative clause rather than to a root clause, see Castroviejo (2006), see also Rett (to appear) for a similar conclusion.

It should also be considered that in German, there is no other instance of an independent clause where the verb stays in its base position. Thus, wh-exclamatives, analyzed as autonomous root clauses, would add an

\footnotetext{
${ }^{32}$ But note that this complementizer can also introduce subjunctive clauses that do not show any traits of factivity. Thus, it will be hard to claim that che expresses 'factivity' per se. Since Northern Italian exhibit the DFC as well, it is more plausible to analyse these con structions on a par with the southern German construction.
} 
exception to the grammar that should be argued for on independent grounds.

All these considerations point into the direction that wh-exclamatives are in fact embedded clauses and get their exclamative interpretation via a (phonologically empty) matrix predicate. V1E (with or without introducing was) on the other hand show all properties of typical root clauses. If this is true, then the result of this discussion is that the seemingly 'marginal' V1E are in fact the core cases of the 'exclamative clause type' in that they are clear cases of root clauses, getting their interpretation in an autonomous way, albeit not in purely syntactic terms (perhaps with the exception of the was/wie introduced V1E). The 'standard' wh-exclamatives then have to be treated as a case of ellipsis of the matrix predicate. I think the discussion in this paper lays the burden of proof on the side of those who advocate that these formally embedded structures are nevertheless autonomous root clauses. The debate about the performative hypothesis is thus re-opened. In which way the hypothesis can be 'modernized', e.g. within the cartographic approach, or for example by assuming that the 'embedded' clause is in these cases always topicalized such that it has direct access to discourse - this is left to future work.

\section{Conclusion}

It was argued that V1E are indeed exclamatives and not merely 'reinterpreted' $\mathrm{Y} / \mathrm{N}$ questions. Furthermore it was shown that a degree component is essential for the exclamative interpretation together with an evaluative component. The discussion of 're-interpretation' lead to a general revision of the concept clause type is syntactically represented as features/operators. It was suggested to decompose clause type into combinations of the state of knowledge ability of speaker and addressee and to connect $\mathrm{V}-\mathrm{C}$-movement to one natural class of these combinations, namely $\mathrm{A}+$. This opens a way to account for the structural ambiguity between $\mathrm{Y} / \mathrm{N}$ questions and $\mathrm{V} 1 \mathrm{E}$. The overall conclusion is that a detailed examination of such minor, 'non-canonical' clause types can provide us with new insights about syntax proper and its interfaces to the semantic/pragmatic component.

\section{References}

Abels, K. 2007. Deriving selectional properties of 'exclamative' predicates. Interfaces and interface conditions, ed. A. Späth, 115 140. Berlin: de Gruyter. Adger, D. 2003. Core syntax. New York and Oxford: Oxford University Press. D'Avis, F. J. 2001. Über ' $w$ Exklamativsätze' im Deutschen. Tübingen: Niemeyer. Barbiers, S., Koeneman, O. \& Lekakou, M. 2008. Syntactic Doubling and the Structure of Chains. WCCFL 26: Proceedings of the 26th West Coast Confer 


\section{Ellen Brandner}

ence on Formal Linguistics, eds. C. Chang \& H. Haynie, 77 86. Somerville, MA: Cascadilla Press.

BAyer, J. \& BRANDNer, E. 2008. On wh head movement and the doubly filled comp filter. WCCFL 26: Proceedings of the 26th West Coast Conference on Formal Linguistics, eds. C. Chang \& H. Haynie, 87 95. Somerville, MA: Cascadilla Press.

BenNis, H. 1998. Exclamatives!. Linguistics in the Netherlands 1998/15, eds. R. van Bezooijen \& R. Kager, 27 40. Amsterdam: John Benjamins.

Bennis, H., CoRver, N. \& DEN Dikken, M. 1998. Predication in nominal phrases. The Journal of Comparative Germanic Linguistics 1, 85117.

BRANDNER, E. 2004. Head movement in minimalism, and V2 as force marking. Syntax and semantics of the left periphery. Interface explorations 9, eds. H. Lohnstein \& S. Trissler, 97 138. Berlin: Mouton de Gruyter.

BRANDNER, E. 2008. On the degree component in exclamatives. Talk given at the workshop La structure fine des types de phrases, Paris, 27.11. 2008.

Castroviejo Miró, E. 2006. Wh exclamatives in Catalan. Barcelona. PhD diss.

Castroviejo Miró, E. 2008. What does it take to embed an exclamative?. Talk given at the University of Konstanz, February 14.

Cheng, L. 1997. On the typology of wh questions. New York and London: Garland.

Cheng, L. \& Rooryck, J. 2000. Licensing wh in situ. Syntax 3.1, 119.

CORVER, N. 1990. The syntax of left branch extraction. Tilburg. PhD dissertation.

Delsing, L. O. 2007. Degree exclamatives in Scandinavian. Talk given at the NORMS workshop on exclamatives, Tromsø, October 2223.

DoetJes, J. 1997. Quantifiers and selection: On the distribution of quantifying expressions in French, Dutch and English. Leiden. PhD diss.

DonAtI, C. 2006. On wh head movement. Wh movement: Moving on, eds. L. Cheng \& N. Corner, 21 46. Cambridge, MA: MIT Press.

Dowty, D. R. 1979. Word Meaning and Montague Grammar. Dordrecht: Reidel.

ElliotT, D. 1974. Towards a grammar of exclamations. Foundations of Language $11,23146$.

Giannakidou, A. 1998. Polarity sensitivity as (non)veridical dependency. Amsterdam: John Benjamins.

Grimshaw, J. 1979. Complement selection and the lexicon. Linguistic Inquiry $10.2,279326$.

Gunlogson, C. 2001. True to form: Rising and falling declaratives in English. Santa Cruz, CA. PhD diss.

Gutièrrez Rexach, J. 1996. The semantics of exclamatives. Syntax at Sunset. UCLA Working Papers in Linguistics, eds. E. Garrett \& F. Lee, 146 162. Los Angeles: UCLA.

Hasegawa, K. 1999. Exklamativsätze im Deutschen und Japanischen. Jena. MA thesis.

HudDleston, R. 1993. On exclamatory inversion sentences in English. Lingua 90, 259269

Jónsson, J. 2007. Icelandic exclamatives: An overview. Talk given at the NORMS Workshop on exclamatives, Tromsø, October 2223.

Kennedy, C. 1999. Projecting the adjective: The syntax and semantics of grada bility and comparison. New York: Garland.

McCawley, N. 1973. Boy! Is syntax easy! Proceedings of the Chicago Linguistics Society 1973/9, 369377.

NäF, A. 1987. Gibt es Exklamativsätze? Satzmodus zwischen Grammatik und Pragmatik. ed. J. Meibauer, 140 160. Tübingen: Niemeyer. 
Neeleman, A., van de Koot, H. \& Doetjes, J. 2004. Degree expressions. The Linguistic Review 21, 166.

Obenauer, H. G. 1994. Aspects de la syntax A barre: Effets d'intervention et mouvements des quantifieurs. Thèse d'état. Université de Pars VIII.

Obenauer, H. G. 2004. Non standard Wh questions and alternative checkers in Pagotto. Syntax and semantics of the left periphery. Interface explorations 9, eds. H. Lohnstein \& S. Trissler, 343 384. Berlin: Mouton de Gruyter.

Portner, P. 2004. The semantics of imperatives within a theory of clausal typing. http://semanticsarchive.net/Archive/mJ1ZGQ4N/PortnerSALT04.

PotTs, C. 2005. The Logic of Conventional Implicatures. Oxford: Oxford University Press.

Poтts, C. 2007. The expressive dimension. Theoretical Linguistics 33.2, 165198.

ReIs, M. 1999. On Sentence Types in German. An Enquiry into the Relationship between Grammar and Pragmatics. Interdisciplinary Journal for Germanic Linguistics and Semiotic Analysis 4, 195236.

RetT, J. (to appear). A degree account of exclamatives. Proceedings of SALT 18.

Rizzi, L. 1996. Residual verb second and the wh criterion. Parameters and functional heads: Essays in comparative syntax, eds. A. Belletti \& L. Rizzi, 63 90. New York and Oxford: Oxford University Press.

Ross, J. R. 1970. On declarative sentences. Readings in English Transformational Grammar, eds. R. A. Jacobs \& P. S. Rosenbaum, 222 272. Waltham, Mass.: Ginn \& Co.

SÆв $\varnothing$, K. 2006. The logical basis of exclamatives. Handout. http://semantics on line.org/2005/12/sb on exclamatives.

Travis, L. 1984. Parameters and Effects of Word Order Variation. PhD disser tation, Cambridge, Mass.: MIT.

Trissler, S. 2005. Wh Exklamative Teil II. Talk given at the University of Konstanz, May, 2005.

TruCKenBrodT, H. 2006. On the semantic motivation of syntactic verb move ment to C in German. Theoretical Linguistics 32.3, 257306.

VANGSNeS, Ø. 2007. Measureless quantificational exclamatives in Northern Norwegian. Talk given at the NORMS workshop on exclamatives, Tromsø, October 2223.

VANGSNES, Ø. 2008. Decomposing manner how in colloquial Scandinavian. Studia Linguistica 62.1, 119141.

WeCHSLER, S. 1991. Verb second and illocutionary force. Views on phrase struc ture. eds. D. Bouchard \& K. Leffel, 177 191. Dordrecht: Kluwer.

Westergatrd, M. \& Ø. A. Vangsnes. 2005. WH questions, V2, and the Left Periphery of three Norwegian dialect types. Journal of Comparative Germanic Linguistics 8, 119160.

ZaefFerer, D. 2001. Deconstructing a classical classification: A typological view at Searle's concept of illocution type. Revue Internationale de Philosophie 2001/ 2, 209225.

Zanuttini, R. \& Portner, P. 2003. Exclamative clauses: At the syntax semantics interface. Language 79, 3981.

Ellen Brandner

Department of Linguistics

University of Konstanz

Universitätsstraße 10

Box D 191

78457 Konstanz

Germany

eleonore.brandner@uni konstanz.de 